website extra

Additional references

appear on the

Evidence-Based

website

com

Source of funding:

NHS Executive Anglia

and Oxford REDD

Directorate UK.

For correspondence:

Ms C B Joy, Cochrane

Schizophrenia Group,

Summertown Pavillion,

Middle Way, Oxford

OX2 7LG, UK. Fax

$+44(0) 1865316023$.
Mental Health

www.ebmentalhealth.

\section{Review: haloperidol is effective for schizophrenia but increases parkinsonism, dystonia, and akathisia}

Joy CB, Adams CE, Lawrie SM. Haloperidol versus placebo for schizophrenia. Cochrane Database Syst Rev 2001;(2):CD003082 (latest version 9 Feb 2001).

\section{QUESTION: In patients with schizophrenia, what are the clinical effects of haloperidol compared with placebo?}

\section{Data sources}

Studies were identified by searching databases including EMBASE/Excerpta Medica (1980 to Feb 1998), Medline (1966 to Feb 1998), PsycLIT (1974 to Feb 1998), and SCISEARCH (1974-98); scanning references of articles; contacting authors; and handsearching high yield journals.
Haloperidol (Hal) v placebo for schizophreniat

\begin{tabular}{|c|c|c|c|c|c|}
\hline \multirow[b]{2}{*}{ Outcomes } & \multirow{2}{*}{$\begin{array}{l}\text { Follow up (no of } \\
\text { RCTs) }\end{array}$} & \multicolumn{2}{|c|}{$\begin{array}{l}\text { Weighted } \\
\text { event rates }\end{array}$} & \multirow[b]{2}{*}{$\operatorname{RRR}(95 \% \mathrm{Cl})$} & \multirow[b]{2}{*}{ NNT (Cl) } \\
\hline & & Hal & Placebo & & \\
\hline \multirow{2}{*}{$\begin{array}{l}\text { No clinician } \\
\text { rated Gl }\end{array}$} & 6 weeks $(2)$ & $30 \%$ & $81 \%$ & $62 \%$ (43 to 75 ) & 2 (1 to 3 ) \\
\hline & 24 weeks (8) & $53 \%$ & $86 \%$ & $31 \%(20$ to 40$)$ & $4(3$ to 5$)$ \\
\hline $\begin{array}{l}\text { No nurse rated } \\
\mathrm{Gl}\end{array}$ & $>6-24$ weeks $(1 \ddagger)$ & $57 \%$ & $100 \%$ & $43 \%$ (13 to 67 ) & 3 (2 to 7$)$ \\
\hline \multirow[t]{3}{*}{$\begin{array}{l}\text { Leaving study } \\
\text { early }\end{array}$} & 6 weeks $(9)$ & $47 \%$ & $54 \%$ & $18 \%$ (5 to 29 ) & 14 (7 to 2029) \\
\hline & 24 weeks (8) & $11 \%$ & $13 \%$ & $44 \%(-3$ to 69$)$ & Not significant \\
\hline & & & & RRI (Cl) & $\mathrm{NNH}(\mathrm{Cl})$ \\
\hline Dystonia & Mean 51 days (3) & NR & NR & $\begin{array}{l}370 \% \text { (70 to } \\
4300) \S\end{array}$ & 5 (3 to 9$) \S$ \\
\hline Akathisia & Mean 49 days $(3)$ & $19 \%$ & $1.5 \%$ & $552 \%$ (54 to 2655$)$ & 6 (3 to 103 ) \\
\hline Parkinsonism & Mean 39 days (4) & $32 \%$ & $1.4 \%$ & $\begin{array}{l}798 \% \text { (157 to } \\
3040)\end{array}$ & 4 (3 to 5$)$ \\
\hline \multirow[t]{2}{*}{$\begin{array}{l}\text { Antiparkinson } \\
\text { drugs }\end{array}$} & $\begin{array}{l}\text { Mean } 10 \text { weeks } \\
\text { (2) }\end{array}$ & $56 \%$ & $6.3 \%$ & $391 \%$ (1 to 2285 ) & 2 (1 to 98 ) \\
\hline & & \multicolumn{2}{|c|}{$\begin{array}{l}\text { Weighted } \\
\text { mean scores }\end{array}$} & \multicolumn{2}{|c|}{ Weighted mean difference (CI) } \\
\hline $\begin{array}{l}\text { Mean BPRS } \\
\text { score }\end{array}$ & 6 weeks (2) & 26.4 & 38.3 & $11.9(6.7$ to 17.0$)$ & \\
\hline
\end{tabular}

†BPRS=Brief Psychiatric Rating Scale; $\mathrm{Gl}=$ marked global improvement; NR=data not reported; RCTs=randomised controlled trials. Other abbreviations defined in glossary; mean follow up, weighted event rates, weighted mean scores, RRR, RRI, NNT, NNH, and Cl calculated from data in article. ҒUnweighted data. §Data reported in article.

\section{Study selection}

Randomised controlled trials (RCTs) were selected if they compared haloperidol (excluding depot forms of the drug*) with placebo in people with schizophrenia or similar, serious, non-affective psychosis. Quasirandomised studies were excluded.

\section{Data extraction}

2 reviewers independently assessed the quality of study methods. All reviewers independently extracted data on methods, participants, interventions, and outcomes.

\section{Main results}

20 RCTs (2120 patients) met the selection criteria (sample size range 12-388 patients). Most studies used haloperidol doses in the range of 4-20 mg/day. Haloperidol was better than placebo for global improvement (table). 1 study reported no statistically significant difference between groups in the number of patients with reduced Brief Psychiatric Rating Scale (BPRS) scores. The pooled results of 2 studies showed better mean BPRS scores for the haloperidol group than for the placebo group at 6 weeks (table). Haloperidol reduced early withdrawals but this effect was attenuated over time (table). Haloperidol increased dystonia, akathisia, parkinsonism, and need for antiparkinson medication (table).

\section{Conclusion}

In patients with schizophrenia, haloperidol is better than placebo for global improvement but increases the rates of parkinsonism, akathisia, and acute dystonias substantially. *See Review: haloperidol decanoate is superior to placebo for schizophrenia [abstract]. Evidence-Based Mental Health 1999 Aug;2:84.

\title{
COMMENTARY
}

Haloperidol has played a pivotal role in the treatment of psychosis. It has been widely used in developed and developing countries and, until recently, was the "industry standard" against which newer medications were compared. In addition to quantifying long standing clinical impressions, this scholarly review by Joy et al reminds us of some sobering clinical facts about the treatment of schizophrenia. Although haloperidol was found to be superior to placebo for the treatment of schizophrenia, many people with the condition did not make an immediate nor complete recovery. Rates of extrapyramidal adverse effects were very high (put more bluntly, unacceptably high).

Unfortunately, the authors did not proceed with a planned sensitivity analysis examining safety and efficacy of haloperidol at different doses compared with placebo. Although little doubt exists that higher doses of traditional antipsychotics are associated with higher rates of extrapyramidal symptoms (EPS), we need more information on the safety and efficacy of low dose traditional antipsychotic medication.

A recent systematic review comparing traditional antipsychotic medication (including haloperidol) with newer medications (the "atypicals") suggested that the often quoted superior side effect profile of newer medications is attenuated when the dose of the comparator medication is in the lower range. ${ }^{1}$ A related Cochrane review is currently underway comparing different doses of haloperidol. Clinicians need advice about the safety and efficacy of low dose haloperidol to make an informed decision about the use of this product and newer medications. For example, newer medications tend be associated with substantial weight gain, which can contribute to long term comorbidity. ${ }^{2}$ Clinicians need quality data to balance the risks and benefits of low dose traditional antipsychotics compared with newer atypical antipsychotics (which are associated with more weight gain, but fewer EPS).

1 Geddes J, Freemantle N, Harrison P, et al. Atypical antipsychotics in the treatment of schizophrenia: systematic overview and meta-regression analysis. BMJ 2000;321:1371-6.

2 Allison DB, Casey DE. Antipsychotic-induced weight gain: a review of the literature.J Clin Psychiatry 2001;62(Suppl 7):22-31. 